\title{
Reading through the Lens of Music: African-American Literature and Music
}

\author{
Redona Boriçi \\ Ph.D. candidate in Literature, University of Tirana \\ Part-time Lecturer at University of Shkoder "Luigj Gurakuqi" \\ Faculty of Foreign Languages
}

\begin{abstract}
Harlem Renaissance is a significant time when African-American writers took pride in their artistic traditions. In order to create an authentic image for themselves, they created remarkable standards in their literature and art. A new tradition, which changed the well-established boundaries of literary creativity, was gaining full recognition among African-American writers. A new tradition, which changed the well-established boundaries of literary creativity, was gaining full recognition among African-American writers. These two genres had a huge impact in the times when the US was creating a cultural hybridity while the reconstruction of the mainstream meant an "open war" to classics. This paper will try to describe the extent to which Jazz and Blues aesthetics influenced into the African-American literature and how it was manifested in characters, structures, and themes that AfricanAmerican writers promoted into their literary work.
\end{abstract}

Keywords: Jazz, Blues, African-American literature, Harlem Renaissance

\section{Introduction}

\section{Music vs literature}

Music constitutes an important aspect of African-American culture and literature. Spirituals, Blues and Jazz offer a broad spectrum of genres. Each of them pertains to a history of its own, closely linked to African roots.

The history of African-American people in the US is linked to suffering, slavery, humiliation and denial of human rights leading to the fight against segregation and racial persecution.

Spirituals, Jazz and Blues, particularly describe their history, but they also provide the strings of hope and strength to overcome the burden during slavery. The slavery songs bear witness of the sufferings, sorrow and relief that this phase is as transitory as their journey in this world while Spirituals connect them to God by offering them faith.

An African-American identity was an aim to be sought and accomplished by many African-American artists and writers starting from the end of the 1980s to the beginning of the 1990s culmination with the Civil Rights Movement. A new breadth of literary movement was evolving aiming at reinventing an African-American image and introducing it to the world as the "personality of the colored people". The aim was more of a duty in the fight for their rights against segregation and cultural discrimination.It could be achieved by creating an authentic image while fighting for it and cherishing its value.

A new, authentic image meant new ideas impervious to time. The new generation's response to the changes of postreconstruction was accompanied by new means of actions, including here the success of Blues and Jazz music.Blues represented a shelter to their sufferings.

Jazz, otherwise called as a continuity of Blues, is stronger. Jazz is an emotion. It is unpredictable in its structure as improvisation, polyrhythm, call-and-response techniques suggest.The aim of the African-American artists was not only to create something authentic but also be part of the American culture. According to Murray, Jazz was a continuity and improvement of Blues. In this way, Jazz became a new way of expressing freely the emotions in each performance. This freedom stemmed spontaneity and creativity. 
In order to establish a status in the American society, African-American literature gave a tremendous contribution to American culture. The new image constructed a literary creativity that consisted of a special structure juxtaposing the grammar rules, techniques and style long held as mainstream with classics. This image embraced another form of art named as asymmetrical.

African-American writers were influenced by Blues and Jazz to write their poetry or novels.Blues literature had a fluid structure while Jazz also had a fluid structure, but yet more sophisticated and complex with strong images and complex syntax.

\section{Methodology}

The qualitative methodology will be used in order to compare and analyze the structures, characters and techniques.Descriptive and analytical aspects will also contribute to determining this approach. A close analysis of Blues and Jazz techniques and characters will be analyzed and compared to Blues and Jazz literature techniques and characters, in order to find out if these two constituted a voice of their own or literature was a stretch of music. The analysis will try to put forward the idea whether the music helped African-American writers in embracing the creation of a new identity or simply provided a means of abandonment of the old and welcoming the new.

\section{The concept of the Harlem Renaissance}

Harlem Renaissance is long considered the Mecca of African -American culture. Nevertheless, Harlem proved to be a strong concentration of diverse elements of people from many parts of the world, not only an African-American experience. By shifting the concept from "Old Negro" into the "New Negro", many African-American intellectuals desired to alter the concept of "Old Negro". The concept of being African-American had always been related to social discrimination and fear. African-Americans had been described more based on some stereotypes rather than for what they really were (Locke et al. ,1925, p.3) Consequently, the "Old Negro" was convinced to see oneself inside this prism and, as a result, there was little chance of acquiring a true understanding of one's real self.

A misconception of the "Old Negro" required for a re-orientation toward something new and more real- something that described the most quintessential aspect of an African-American life. In this way, the New Negro became a new way of thinking; a way of discerning the position that an African-American constituted in the USA rather than what he was made to believe for years. This re-evaluation of the way a "New-Negro" thought was a kind of feeling that came from within; something that was free from any outside influence. (Locke, 1925, p.4)

The "New-Negro" had to find the way to channel the new self-expression and a worthy approach to achieve it was through music and literature. The bond that bounded African-Americans together with people from other parts of the world was a strong one. A bond that united them in a common problem, namely the race. It enabled them to reconstruct the problem. The race was a name rather than a fact for many African-Americans. Harlem was a place of group-expression focusing on feeling toward life, past and future. As aforementioned, the purpose of many Harlem Renaissance writers was not only to reexamine their true self but also to express their viewpoints on future. It otherwise became, as Lock pointed out, a race capital. It enabled them to think what was theirs and what was bogus. It helped them not only become a whole strong body of equally-minded people who were struggling not only to make the African-American literature worth of American literary canon but also empower theAfrican-American literature to contribute and enrich the American literature and art.

The "New Negro", while changing perspective, was in a constant inner race while moving toward the objectives that had been set. According W.E.B Du Bois, the New Negro was in a double-consciousness. In Du Bois' thought, it is the veil that grants Black Americans a double- consciousness (Du Bois, 2008). It is the feeling of non-belonging that mostly worried Du Bois. The feeling of not belonging, even to one's home, and looking oneself through the eyes of another as "One ever feels his twoness, - -an American, a Negro; two souls, two thoughts, two unreconciled strivings; two warring ideals in one dark body" (Du Bois, para 3). Nevertheless, this strive was not all lost. Du Bois pledged to obtain the self-consciousness and empower African-Americans to regain their true best representation of themselves by being African and American at the same time without being judged by the color of their skin. Consequently, America would also benefit from AfricanAmericans since cooperation would finally implore for a better America. However, it is this double- consciousness that made many African-Americans not capable of fully excelling in some fields of life since they were torn between the ideals of an African-American and the ideals the white society had imposed to them (Gutenberg, 2008). Through these trials and 
errors, African-Americans managed to see behind the veil the true value of themselves- managed to revalue their selfrespect and self-realization.

\section{Only in this way America would be able to appreciate the true conformity to American ideals}

Work, culture, liberty,-all these we need, not singly but together, not successively but together, each growing and aiding each, and all striving toward that vaster ideal that swims before the Negro people, the ideal of human brotherhood, gained through the unifying ideal of Race; the ideal of fostering and developing the traits and talents of the Negro, not in opposition to or contempt for other races, but rather in large conformity to the greater ideals of the American Republic, in order that some day on American soil two world-races may give each to each those characteristics both so sadly lack. ( Du Bois, 2008,para. 12)

E.Bowen (1895) in his "An appeal to King" had the same idea about the cooperation among races in America. For Bowen, the veil was a king, an invisible one, who exerted power and control. Nonetheless, the revolution of morals had begun. The changes that the "New Negro" was undertaking were changes that would give positive changes in the society. Bowen also believed that the race problem was also of a wider range and one could not only focus on the race problem in America. He believed that the Negro should also encompass a wider definition-a human race problem (27). Bowen also acknowledged that the Negro was also seeking to define himself among other men in America. In this way, America could go toward a homogeneity in sentiment and this sentiment would enable any men develop one's ability to do good in society (28). It was a plea for good education, for the betterment of living conditions and, consequently, for a better status in American society. In order to acquire a distinctive voice, many American writers had to find a distinctive form of expression to show their authentic voice in American literature.

\section{The sounds of African-American Literature}

According to Zora Hurston (1997), the characteristics of Negro expression included the use of simile and metaphors, the use of double-descriptive as well as the use of verbal nouns (57). Asymmetry was another important of African American literature and art. As music relied on improvisation and deepest feelings emerging in notes, each unit had a rhythm but as a whole, it was asymmetrical (60). Music, literature and art were a means to escape the chains of past, to free the soul and turn sentiments into golden words with almost sacred words for African-Americans. Spirituals were the utterance of pain and suffering, Blues chiseled true feelings while Jazz incorporated soul and body into a truly genuine voice.

Another important influence in the writing of many African-American writers was also the blues and jazz aesthetics. In order to obtain and solidify a unique voice of their own, many African-American writers were influenced by the techniques and styles of Blues and Jazz. Langston Hughes managed to include both Blues and Jazz in his writing in assembling the Blues notes and the Jazz improvisation into a single voice.

An important facet of Blues aesthetics was double-entendre. Oftentimes, Blues is related to sadness, pain and suffering. Nevertheless, double-entendres are most times associated with aspects of sexuality in Blues. African-American writers took double-entendres and gave them acceptable and respectable connotation for the society. Travel themes played an important part in many blues song. As in Ma Rainey "Walking Blues," (1923) women had to walk, to survive and make it. There was no turning back. The woman had to go on with her life and sing the Blues. Bearing no more the longing for a beloved one, the independent living and discovering the world alone by travelling, the travelling of the older generations as slaves from other countries, the

search of freedom as a long "travel" toward equality were topics chosen and elaborated by African-American writers.

Another important element of African-American literature was repetition. As in "Cross Road Blues," (1936) Robert Johnson intensifies his inner feelings by using the metaphor of crossroad "...... went down to the crossroad, fell down on my knees". Writers used repetition as to intensify an emotion, a feeling. In "Weary Blues" (1987) Hughes repeats, "Ain't got nobody in all this world, Ain't got nobody but ma self." where he portrays his inner struggle to succeed in a society in which he is practically alone.

A Blues Couplet, used by many Blues singers, consists of twelve bar blues, mainly of 3 lines where the first line is repeated in the second while on the third the improvisation takes place. The rhyme usually consists of AAB as in "St. Louis Blues" (1914): 
Oh, that St. Louis woman with her diamond rings

She pulls my man around by her apron strings

\section{And if it wasn't for powder and her store-bought hair}

A major technique of Jazz was improvisation. The singer was free to improvise, to give a new version of the same piece of art. The Jazz singers called for a different tune and received a response. The call-and- response technique became a very useful technique in many writings of African-American literature. It enabled many writers to call for some kind of action or revolt and asked for a response from the reader. The message was like a hidden code that only African-Americans could understand and support. Meanwhile, it became very difficult to decipher by others. The message was gaining the qualities of a music coda- an afterthought of what was left from the past and what had yet to come in the future.

In "Weary Blues," (1987) Langston Hughes requested the union between the author and the reader. The musician who was playing the weary blues was not a famous artist. Yet, he succeeded in mirroring the reality of that time. His notes on the keys create the feeling of anticipation and fair. It was fair but also determination to be free and authentic:

With his ebony hands on each ivory key

He made that poor piano moan with melody.

O Blues! (23)

Blues is the sound that moans. It is a revelation from the soul- the soul of an Afro-American seeking dignity. The Blues unites Afro-Americans together to this reality and unites them to sing to it. Blues also inspires them to sing to their past. The piano is a mirror of the pain that is "....coming from a black man's soul." (23) Blues is also talent and strength.

Blues is embellished with a transformative force, which is ongoing and enriches. Music symbolizes a form of freedom, a form of expression and a quest for appreciation. Consequently, Hughes believed that Blues was a mixture of past and present.

Blues represented a rather dimmer picture of the situation in "Tornado Blues," (Brown,

1901):

Destruction was a-drivin' it and close behind was Fear,

Desctruction was a-drivin'it and hand in hand with Fear,

Grinnin' Death and skinny Sorrow was a-bringing'up de rear. (68)

It displayed feelings of destruction, despair and fear. Following the common AAB rhyme as well as repetition, Brown's voice was immediate, looking for an urgent response from African-American community. A voice Bowen and Locke had also acknowledged among African- Americans.

In "Jazzonia," Hughes (1987)depicted Jazz as a new form of expression. He embraced new techniques in his writing such as repetition, rhetoric questions as well as improvisation as quintessential techniques of Jazz. "Jazzonia," represented a story at a cabaret in Harlem whereby six musicians play Jazz music and another Afro-American was sitting watching the show as well as the girl who was dancing to the music. Her beauty is indescribable. Hughes compared her to Cleopatra's beauty and boldness by posing rhetoric questions to the reader in the form of a call-and-response: "Were Eve's eyes ....Just a bit to bold?" and "Was Cleopatra gorgeous in a gown of gold?"(24). Hughes calls the reader to take pride in what is African-American by constructing in this way what is theirs. Jazz is offered as a bold expression, as bold as the dancer's eyes. It is not only her eyes that are bold. She lifts high the dress of silken gold (24). In this way, Jazz and literature are creating a form of free expression for African-American literature; a free form probably going counter some norms. In "Cabaret," Hughes intensifies the acceptance and identification of sexuality while in "Jazz Band in a Parisian Cabaret," Hughes offers a more inclusive approach compared to "Cabaret" and "Jazzonia". Jazz is for everyone rich and poor, lords and ladies. It is the music that touches the soul to everyone- the tune cries and laughs at the same time (106).

In "Harlem Dancer" by Mackay (1922) one remarks a difference. The dancer is as perfect as in "Jazzonia". Her beauty and her movements are beautiful but she has to put "her false smiling face" in order to please the audience. It is the veil of Du 
Bois or the mask of Dunbar that somehow makes the dancer stay in between two parts of the game. Mackay believed in the need to break free that wall in order to be appreciated and accepted. In this way, African-American literature would be supported and become an important part of American literature. It was a form of rebellion but also pride and recognition of one's values.

AsHughes (1926) reflected in "The Negro Artist and the Racial Mountain" : ". . the Negro artist offers his racial individuality, his heritage of rhythm and warmth, and his incongruous humor that so often, as in the blues, becomes ironic laughter mixed with tears" (693). Jazz proved to be a new form of expression sometimes getting the form of rebellion or protest. Sometimes it became a single form of individual self-expression.

\section{Conclusion}

Many African-American writers shared the common belief that African-Americans had to give their contribution to the American culture and literature. In order to achieve this aim, African-American writers had to choose a new aesthetics that was different from white writers. In this way, they would not only prove their value but also contribute to the enrichment of African-American culture in general and literature in particular. Jazz and Blues aesthetics proved to be very effective ways of providing the audience with new pieces of writing accompanied by a new style. This quintessential form of expression would enable African-American thought to constitute an important part of American literature but it would make them feel proud of their identity and talent.

Music is presented as a form of expression to a people.Blues and Jazz were forms of expression of feeling, suffering, but also amusement. Blues music represents the suffering, the past of African-American history. The blueprint also represents a linkage between Afro-Americans to remember the past but also to appreciate what the future could bring. On the other hand, Jazz presents us a more complicated way of amusement or escapism from life's suffering.

\section{VI.References}

[1] Baker, Houston A. (1987) Blues, Ideology, and Afro-American Literature: A Vernacular Theory. Chicago: University of Chicago Press .

[2] Berry, Faith. (1983) Langston Hughes: Before and Beyond Harlem. Westport: Lawrence Hill.

[3] Bessie Smith, and Billie Holiday. New York: Vintage.

[4] Borshuk, M. Swinging the vernacular: jazz and African American modernist literature. New York: Routledge.

[5] Brow, Sterling A. (1901) The collected poems of Sterling A. Brown. Northwestern University Press. 68-69.

[6] Charters, S. (1063) The Poetry of the Blues. New York: Oak Publications.

[7] Davis, Angela Y.(1998) Blues Legacies and Black Feminism: Gertrude "Ma" Rainey,

[8] Du Bois, W.E.B. (2008) The souls of black folk. The Project Gutenberg Ebook. Para 3-12.

[9] Gates, Henry L. et. al., (2007) The New Negro: Readings on Race, Representation and African-American culture 18921938. Princeton University Press. 27-28.

[10] Gennari, John. (1991) “Jazz Criticism: Its Development and Ideologies." Black American Literature Forum 25.3.

[11] Handy, William C., St. Louis blues Retrieved from http://www.metrolyrics.com/saint-louis-blues-lyrics-louis-armstrong.html

[12] Hawking, Alfonso W. The jazz trope: a theory of African American literary and vernacular culture. 1957.

[13] http://blueslyrics.tripod.com/lyrics/ma_rainey/walking_blues.htm.

[14] Hughes, L. (1926) The Negro Artist and the Racial Mountain. The Nation, 692-94

[15] Hughes, L. (2001). A collection of works of Langston Hughes: The poems 1921-1940.

[16] Hurston, Zora N. (1997) Sweat. Rutgers University Press.57-60.

[17] Johnson, R. Cross road blues. Retrieved from https://www.youtube.com/watch?v=GsB_cGdgPTo

[18] Locke, A. (1925) The New Negro: Voices of the Harlem Renaissance. Simon and Schuster. 23-24,106. 
[19] McKay, C. (1922). Harlem dancer. Retrieved from http://harlemshadows.org/the-harlem-dancer.html.

[20] Rainey, Ma.Walking Blues.Retrievedfrom

[21] University of Missouri Press, 23-24,106. 